\title{
Autochthonous Hepatitis E Virus Infection in Europe: A Matter of Concern for Public Health?
}

\author{
José-Manuel Echevarría \\ Department of Virology, National Centre of Microbiology, Instituto de Salud Carlos III, Madrid, Spain
}

\begin{abstract}
Human hepatitis E virus (HHEV) is the proposed name for a diverse group of RNA viruses from the family Hepeviridae that cause acute hepatitis among humans. Waterborne strains are regularly imported into Europe by international travelers, and virus transmission of zoonotic strains via contaminated aliments is involved in autochthonous cases. Therefore, in Europe, hepatitis E displays a unique dual character, having features of both imported and autochthonous infections. Environmental involvement of waterborne and zoonotic diseases puts alimentary safety at risk. In addition, it may lead to serious health problems derived from persistent infection among patients with immune impairment due to organ transplant, cancer, or human immunodeficiency virus infection. Although the European health authorities know at present that HHEV represents a problem worthy of consideration, the actual incidence of the disease in Europe is unknown, and attempts to ascertain the prevalence of the infection is hampered by unresolved technical issues. In order to determine the burden of hepatitis $\mathrm{E}$ in Europe, the World Health Organization Regional Office and the European Centre for Disease Prevention and Control should pay specific attention to hepatitis $E$, and research efforts in the continent should be transnational and collaborative. Development of a specific European network for hepatitis $\mathrm{E}$ would help to achieve these goals.

(C) 2014 The Second Affiliated Hospital of Chongqing Medical University. Published by XIA \& HE Publishing Ltd. All rights reserved.
\end{abstract}

\section{Introduction}

\section{The human hepatitis $E$ virus}

The family Hepeviridae consists of a not yet fully classified group of viruses in vertebrates, including fish, birds, and mammals. Hepatitis E virus (HEV) belongs to the genus Hepevirus, which includes four genotypes capable of infecting human beings. In a recent review, a novel classification of the

Keywords: Hepatitis; Hepatitis E virus; Epidemiology; Europe; Human. Abbreviations: anti-HHEV, antibody to HHEV; ECDC, European Centre for Disease Prevention and Control; EIA, enzyme-immunoassay; HEV, hepatitis $E$ virus; HHEV, human hepatitis E virus; HIV, human immunodeficiency virus; ORFs, open reading frames; RIBT, recombinant immunoblottest.

Received: 2 December 2013; Revised: 26 December 2013; Accepted: 3 January 2014

DOI of original article: 10.14218/JCTH.2013.00027

Correspondence to: José M Echevarría, Centro Nacional de Microbiología, Crtra, Majadahonda-Pozuelo, Km2. 28220 Majadahonda, Madrid, Spain. Tel: +34918223634, E-mail: jmecheva@isciii.es family into two genera was proposed, with the avian and mammal viruses drawing a single genus and the viruses from fish a second one. ${ }^{1}$ HEV strains found among humans belong to a single viral species within the first genus consisting of six separate genotypes. This species was nominated as human HEV (HHEV). Genotypes 1 and 2 (HHEV1, HHEV2) are exclusive of human beings, and genotypes 3 and 4 (HHEV3, HHEV4) are shared by humans with other mammals. In addition, some HEV strains found in wild boar drew two additional genotypes of HHEV, and HEV strains specific for birds, bat, rodent, and ferret would constitute, respectively, four distinct species within the genus.

The HHEV virion is a spherical-shaped particle, approximately $30 \mathrm{~nm}$ in diameter, consisting of a single structural protein (the core protein) that arranges in different ways into distinct structural units. The viral genome consists of a linear, single stranded, positive sensed, 3'-capped single RNA species, 7.3 kilobases in length organized into three open reading frames (ORFs). ${ }^{2}$ Four functional proteins involved in viral replication are encoded by ORF1. ORF2 and ORF3 sequences specify the virion core protein and a small phosphoprotein of unknown function, respectively (Fig. 1).

\section{Main epidemiological and clinical features of HHEV}

Though HHEV is thought to constitute a single serotype, no experimental evidence of cross-protective immunity among the different HHEV genotypes infecting humans exists, and these genotypes draw two separate groups in regard to their epidemiological features (Table 1). HHEV1 and 2 are exclusive to humans, restricted to particular geographical areas, and spread often among the children as waterborne, open epidemic outbreaks. In contrast, HHEV 3 and 4 are adapted to mammals from different orders, distributed worldwide, and infect humans sporadically through zoonotic transmission or by consumption of contaminated aliments. Pig, wild boar, deer, moufflon, cattle, rat, rabbit, and mongoose are known potential reservoirs of HHEV either in farms or in the wild.

Diseases caused by these HHEV genotypes share identical clinical features among themselves and other acute viral hepatitis. Asymptomatic infection seems a common event as well. Though HHEV1 infection has a high fatality rate (20$25 \%$ ) among pregnant women, the disease can in any other cases be mistaken as hepatitis $A$ by clinicians in the regions where this agent remains endemic. In addition to jaundice, anorexia, abdominal pain, and hepatomegaly are often found among patients with acute hepatitis due to HHEV1, other symptoms like fever, nausea, or vomiting are less frequent. The case fatality rate ranges from 0.5 to $4 \%$ among patients requiring hospitalization, most likely a small minority overall. 


\begin{tabular}{lllllllll}
0 & 1 & 2 & 3 & 4 & 5 & 6 & 7.3 \\
$\mathrm{~L}$ & 1 & 1 & 1 & 17 & 1 & 1 \\
\hline
\end{tabular}

Genomic RNA (7.3Kb)

Cap

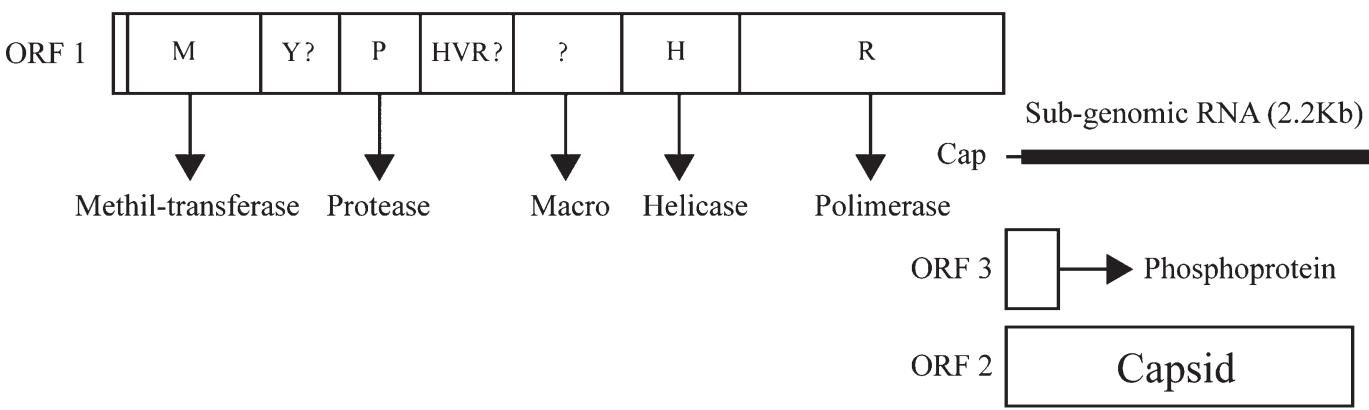

Fig. 1. Organization of the HHEV genome and products specified

To date, persistent viral infection by HHEV1 has not been reported.

Detailed clinical data from patients with acute hepatitis due to HHEV3 are rare. When a comparison was performed, most cases reported resembled cases of acute hepatitis $A{ }^{3}$ Among 33 individuals involved in an outbreak of HHEV3 infection on a cruise ship, 11 suffered acute hepatitis, and 22 had asymptomatic infection. ${ }^{4}$ Jaundice was observed in seven cases, and abnormal liver enzyme levels were detected only among the patients displaying acute disease. The likelihood of infection was significantly higher among men than women. Complications of the HHEV3 infection are not frequent, and mortality was often associated with underlying alcoholic cirrhosis. Virus persistency resulting in chronic hepatitis has been reported among patients with immune impairment, including transplant recipients, hematological patients, and human immunodeficiency virus (HIV) patients. ${ }^{5}$

HHEV is the main cause of acute viral hepatitis in developing countries. HHEV1 infection has led to epidemic outbreaks and sporadic cases in Southern and Central Asia, the Far East, Africa, and the Caribbean. Most patients involved were children. HHEV2 has been responsible for outbreaks in the African continent. Sporadic cases of acute hepatitis due to HHEV3 or 4 are regularly recorded in Europe and in the Americas, as well as in China, Japan, Korea, and Taiwan. In the USA, a study performed at the national level among 154 patients with acute hepatitis found a frequency of locally acquired hepatitis E of $9.7 \%$, where all cases tested positive for HHEV3 infection. ${ }^{6}$ Autochthonous cases due to this genotype have also been found in other American countries like Argentina, Bolivia, Brazil, Mexico, Venezuela, and Uruguay, the frequency ranging from 1.6 to $30 \%$ in the series. ${ }^{7}$ HHEV 3 and 4 do not cause open epidemics but may be involved in small outbreaks.

The prevalence of specific antibody to HHEV (anti-HHEV) may display wide regional and population-based variations. ${ }^{8}$ The greatest regional differences occur among children, and data show that the virus spreads earlier in life in Asian populations relative to regions where HHEV1 is absent. Generally speaking, HHEV1 shares with HAV many epidemiological similarities, but is less prevalent among the population of endemic regions because of the decrease in viral particle stability. Clusters of high endemicity have, however, been reported for specific populations from China and SouthEastern Asia. HHEV3 is prevalent everywhere, but unexplained regional differences in prevalence have been found within the USA. ${ }^{9}$ Regarding HHEV2 and 4, there is little data available and insufficient to draw an epidemiological picture.

\section{Laboratory diagnosis of hepatitis $E$}

Laboratory assays for specific antibody testing have been developed with recombinant antigens from the antigenic viral proteins, mainly the core protein. Early serological diagnosis is based on detection of the anti-HHEV IgM response by enzyme-immunoassay (EIA) testing. Like in other viral

Table 1. Main epidemiological features of the four HHEV genotypes infecting humans

\begin{tabular}{lllll}
\hline Feature & HHEV1 & HHEV2 & HHEV3 & HHEV4 \\
\hline Regional distribution & Tropical regions & Africa ${ }^{a}$ & Worldwide & East Asia, Europe \\
Epidemics & Yes & Yes & No & No \\
Waterborne & Yes & Yes & No & No \\
Spread among children & Yes & Yes & No & No \\
Known animal reservoirs & No & No & Yes & Yes \\
Foodborne & $?$ & $?$ & & Yes \\
\hline
\end{tabular}

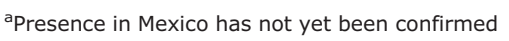


infections, samples reactive in EIA can be re-tested by recombinant immunoblottest (RIBT) for confirmatory purposes. The data available support the reasonable robustness of the current assays for anti-HHEV IgM testing in the diagnosis of acute hepatitis $E$, and confirmed reactivity for anti-HHEV IgM is sufficient for diagnosis. Because primary infection by human cytomegalovirus and Epstein-Barr virus may cause transient, false-positive results for anti-HHEV IgM by RIBT, specific testing for acute primary infection of these viruses is suitable when molecular diagnosis is not performed or viremia is not detected. ${ }^{10}$ Seroconversion to anti-HHEV IgG antibody on follow-up provides a late, additional confirmation, and is the only diagnostic criterion fulfilled in exceptional cases.

Molecular diagnosis is based on amplification of selected sequences from the ORF1 region of the viral genome. The antibody detection window extends for about two weeks, and viremia persists at detectable levels for a variable period of time. Viremia levels are lower than in other forms of acute viral hepatitis, and target degradation during storage impairs the retrospective diagnosis of the disease. Testing of stool samples may help when viremia is not detected. Commercial tests for HHEV genome detection have limited availability in the market.

Therefore, diagnostic criteria for acute hepatitis $E$ in serum samples are as follows: 1. IgM negative, RNA positive (window period); 2. IgM positive, RNA positive (early seroconversion stage); 3. IgM positive, RNA negative (postseroconversion stage); and 4. Seroconversion to IgG antibody on follow-up (Fig. 2).

\section{The burden of HHEV in Europe}

\section{Features of acute hepatitis $E$ in the continent}

The incidence of acute hepatitis $E$ in Europe is unknown. Prospective, population-based studies have not been performed by any country, and broad transnational studies have not been achieved, neither in the full continent nor within the European Union. Hepatitis $\mathrm{E}$ is not included among the Health Topics of the European Center for Disease Control's (ECDC) web page, and a search of documents under the term "hepatitis $E^{\prime \prime}$ in that page, to date, yielded zero results. Exploration of the web page of the WHO Regional Office for Europe rendered identical, disappointing results. Data for estimating the burden of the disease in the continent can be extracted from retrospective case series or prospective studies, although these studies lack epidemiologic value.

Series reporting of a significant number of cases ( $>10$ cases) of acute hepatitis E confirmed by molecular testing have been communicated from Italy, France, the United Kingdom, the Netherlands, Germany, Spain, Sweden, Hungary, the Czech Republic, and Finland. In shorter series or individual case reports, PCR confirmed cases were found inseveral of these countries and also in Greece, Austria, Norway, and Portugal. The disease is, therefore, likely present all over the continent.

Data reported from the United Kingdom, Germany, Spain, Italy, Sweden, and Finland showed that importation of HHEV1 into Europe by international travelers arriving from Asia or Africa is a regular event (Table 2). Cases secondary to such importations have never been communicated, though it seems unlikely that they were ever investigated properly. Environmental studies dedicated to evaluate the impact of these events on the contamination of water and waterfiltering organisms are very scarce, but suggest that it may exist. HHEV1 was reported twice from the urban sewage from Barcelona, Spain, and was found in $15 \%$ of raw sewage samples from wastewater treatment plants evenly distributed through Italy. ${ }^{21-23}$ HHEV was also found in mussels cultivated in Spain, but genotyping of the viral strains was not performed. ${ }^{24}$

In addition to an imported disease, hepatitis $\mathrm{E}$ is an autochthonous disease in Europe. Recent studies involving wide series of patients with acute hepatitis of unknown origin reported that HHEV has an overall frequency ranging from 3.3

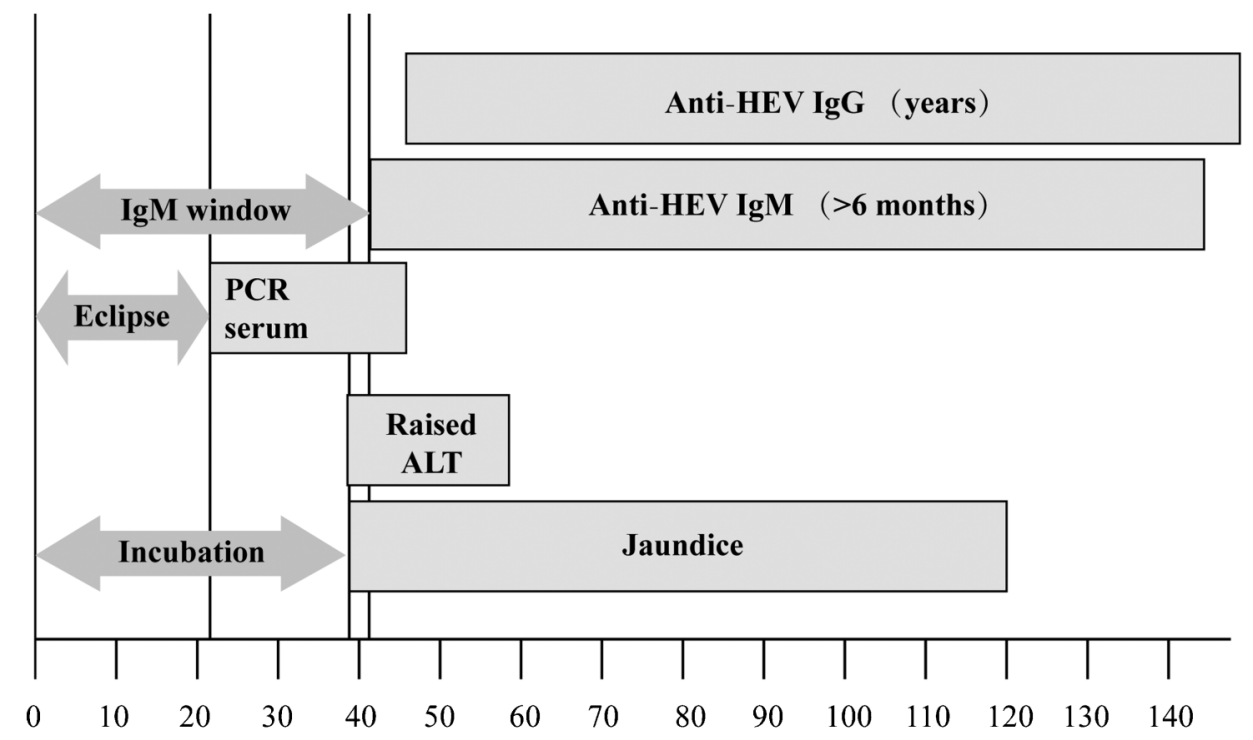

Days after infection

Fig. 2. Evolution of viral diagnostic markers in serum during acute hepatitis $E$ 
Table 2. Main reports describing cases of imported hepatitis $E$ into Europe

\begin{tabular}{llll}
\hline Country & $\begin{array}{l}\text { Patients } \\
\text { tested }\end{array}$ & $\begin{array}{l}\text { Imported } \\
\text { hepatitis E }\end{array}$ & Reference \\
\hline United Kingdom & $179^{\mathrm{a}}$ & 146 & 11 \\
& 329 & 296 & 12 \\
Germany & $76^{\mathrm{a}}$ & 21 & 13 \\
Italy & 651 & 112 & 14 \\
& 52 & 19 & 15 \\
Spain & 277 & 14 & 16 \\
& $49^{\mathrm{a}}$ & 13 & 17 \\
Finland & $67^{\mathrm{a}}$ & 24 & 18 \\
Sweden & 97 & 22 & 19 \\
\hline
\end{tabular}

aPatients selected because prior diagnosis of HHEV infection

to $55.7 \%$. In total, 273 of 4,227 patients $(6.5 \%)$ with locally acquired infections tested positive (summarized in Table 3). The frequency of these infections ranged from 3.3 to $10 \%$, both figures corresponding to series from the United Kingdom. In addition, screening of blood units from healthy Dutch donors for HHEV RNA over two years found a rate of actual infection of $0.03 \%$ (13 positive units from 40,176 tested). ${ }^{29}$ Nine donors lacked, however, anti-HHEV, and only two of four anti-HHEV-positive donors tested positive for antiHHEV IgM. A recent look-back study performed in Germany failed to demonstrate that RNA-positive units had transmitted HHEV to recipients. ${ }^{30}$

These autochthonous HHEV infections were mostly due to HHEV3, were more common among men aged over 40 than among women, younger men, children, or adolescents, and were clinically mild. These are, therefore, the most significant data available at present for understanding the extent of European patient suffering from locally acquired hepatitis $\mathrm{E}$ and for estimating the burden of the disease in the continent. However, other data must be taken into account for a proper evaluation of the issue.

\section{Clinical complications and viral persistency}

The first set of additional data to consider regards the outcome of the acute infection. Transient neurological disorders were recorded in $5.5 \%$ of 126 patients with acute hepatitis due to HHEV3 admitted into two hospitals in France and the United Kingdom. ${ }^{31}$ Four had underlying immune impairment, and the most frequent disorder observed was polyradiculopathy. This neurological complication was also reported from two immunologically normal patients in a second communication from Marseille, France. ${ }^{32}$

Another exceptional outcome more common than neurological complications is the establishment of persistent HHEV3 infection among the immunocompromised. Such persistency was documented among solid organ transplant recipients (kidney, liver, and heart), patients with hematological cancers, and patients infected by HIV from France, Germany, The Netherlands, and Spain. ${ }^{33-38}$ Development of chronic hepatitis that evolved to liver cirrhosis in association to persistency has been widely documented. After the etiological diagnosis, the persistent infection could be successfully treated with interferon or ribavirin. Surveillance of HHEV infection among transplant recipients, leukemic children, and HIV-infected patients should, therefore, be considered in Europe.

\section{Spread of HHEV4 into Europe}

The discovery of HHEV4 in swineherds from Germany, The Netherlands, and Belgium was soon followed by the report of locally acquired HHEV4 infections in European patients with acute hepatitis. Most reports were from France, ${ }^{39}$ but a small outbreak of HHEV4 infection was communicated from Italy. ${ }^{40}$ This event was linked to consumption of infected shellfish. Analysis of available cases suggests that the incidence of HHEV4 might be increasing in Europe, and the genetic diversity displayed by the viral strains demonstrates that the spread of this genotype in the continent did not originate from a single, recent event. In addition to autochthonous cases, importation of HHEV4 from the South East of Asia into Europe by international travelers has been communicated. ${ }^{41}$

\section{Prevalence of anti-HHEV among the population}

Epidemiological testing for anti-HHEV is limited by the lack of genotype-specific assays and the lack of standardized methods for screening IgG or total specific antibody. ${ }^{8}$ Results obtained in the antibody surveys from different populations may show wide variability when different methods for antibody testing are used. ${ }^{42}$ RIBT is often used to confirm the specificity of the results obtained by screening assays in other low prevalent viral infections (i.e., HIV and hepatitis $\mathrm{C}$ virus infections), but the use of this test for HHEV remains controversial. Development of genotype-specific tests is necessary to improve anti-HHEV surveys, and efforts of standardization through collaborative studies are required

Table 3. Main reports describing cases of hepatitis E acquired in Europe

\begin{tabular}{lllll}
\hline Country & Patients tested & Locally-acquired hepatitis E & Frequency, & Reference \\
\hline United Kingdom & 329 & 33 & 10.0 & 12 \\
& 836 & 28 & 3.3 & 3 \\
Hungary & 139 & 13 & 9.4 & 25 \\
France & 1203 & 116 & 9.4 & 26 \\
The Netherlands & 431 & 16 & 3.7 & 27 \\
Italy & 309 & 25 & 8.1 & 28 \\
Spain & 651 & 4 & 3.4 & 14 \\
\end{tabular}


Echevarría JM: Hepatitis E in Europe

Table 4. Prevalence of anti-HHEV among the general population of Europe

\begin{tabular}{|c|c|c|c|c|c|}
\hline \multirow[b]{2}{*}{ Country } & \multirow[b]{2}{*}{ Number of samples } & \multicolumn{3}{|c|}{ Anti-HHEV prevalence, $\%$} & \multirow[b]{2}{*}{ Reference } \\
\hline & & Children & Adults & Overall & \\
\hline United Kingdom & $\begin{array}{l}710 \\
1591\end{array}$ & - $2.0-3.0$ & $\begin{array}{l}3.9 \\
5.0-27.0\end{array}$ & $\begin{array}{l}- \\
13.0\end{array}$ & $\begin{array}{l}43 \\
44\end{array}$ \\
\hline Italy & $\begin{array}{l}1889 \\
3511\end{array}$ & $\begin{array}{l}- \\
-\end{array}$ & $\begin{array}{l}2.6 \\
2.9\end{array}$ & $\begin{array}{l}- \\
-\end{array}$ & $\begin{array}{l}45 \\
46\end{array}$ \\
\hline San Marino & 2233 & - & 1.5 & - & 47 \\
\hline Spain & $\begin{array}{l}2529 \\
2305^{a}\end{array}$ & $\begin{array}{l}4.6 \\
0.5\end{array}$ & $\begin{array}{l}7.3 \\
2.1\end{array}$ & $\begin{array}{l}6.0 \\
1.1\end{array}$ & $\begin{array}{l}48,49 \\
50\end{array}$ \\
\hline Germany & $4422^{a}$ & - & 17.0 & - & 51 \\
\hline The Netherlands & $7072^{a}$ & $0-0.3$ & $1.4-6.4$ & 1.9 & 52 \\
\hline
\end{tabular}

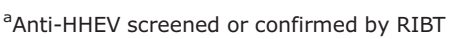

to support future surveys and for interpreting the data collected during the last two decades.

Surveys of anti-HHEV with samples representative of the general population stratified by age have been performed in six European countries (Table 4). Four of them involved children, with an overall prevalence ranging from 1.1 to $13 \%$. The prevalence was always lower than $5 \%$ among children, and it rose to 17 and $27 \%$ among adults from Germany and the United Kingdom, respectively. Studies involving significant collections of samples from blood donors ( $\geqslant 500$ samples) have, in addition, been performed in France, Germany, Portugal, Spain, and the United Kingdom. But from a single communication from France, which reported an unexpectedly high rate, ${ }^{53}$ the prevalence found ranged from $2.5 \%$ in Portugal to $16 \%$ in the UK, matching closely the rates obtained among the general population of adults in Western Europe. $^{8}$

Many reports in regard to the prevalence of anti-HHEV among particular population segments have been communicated from Europe. In the last five years, communications reporting prevalence rates higher than the rates found among controls involved farmers and slaughterhouse workers (19$50 \%)$, forestry workers $(18-31 \%)$, and hemodialysis patients, kidney transplant recipients, and psychiatric patients (18-37\%) from Denmark, France, Germany, Spain, and the United Kingdom. These data suggest that people involved in the industry of swine livestock or developing professional activities in close contact with nature, and particular groups of hospital patients possess a special risk of exposure to HHEV. However, the factors explaining such a risk are mostly unknown.

\section{Considerations about the incidence of the disease, the prevalence of the infection, and the ways of transmission}

Although it has been reported that HHEV3 infection may be symptomless in about two-thirds of cases, ${ }^{4}$ this estimation was based on a single epidemic event that developed on a cruise ship and cannot be generalized. It is, therefore, difficult to estimate if the rates obtained from antibody surveys in Europe match the apparent sporadic nature of the disease among the population.

In addition, some studies recorded regional differences in the frequency rates of hepatitis $\mathrm{E}$ and antibody prevalence within a given country. Such observations were made in the US, France, and the United Kingdom. Updated data from Spain suggest that the frequency of the disease could be up to 20 -fold higher in the Northern regions than in the South of the country (Table 5) and confirmed results from a former

Table 5. Regional incidence of autochthonous hepatitis E in Spain estimated from retrospective data of laboratory diagnosis (about 700 suspected cases studied by the National Centre of Microbiology, 2007-2012)

\begin{tabular}{|c|c|c|c|c|}
\hline Region & $\begin{array}{l}\text { Population, } \\
\text { million inhabitants }\end{array}$ & Hospitals involved & $\begin{array}{l}\text { Locally-acquired HHEV } \\
\text { infections diagnosed }^{a}\end{array}$ & $\begin{array}{l}\text { Rate per million } \\
\text { inhabitants }\end{array}$ \\
\hline Asturias & 1.05 & 3 & 13 & 12.4 \\
\hline Leon $^{b}$ & 0.50 & 2 & 6 & 12.0 \\
\hline Basque Country & 2.11 & 5 & 11 & 5.2 \\
\hline Cantabria & 0.58 & 1 & 2 & 3.4 \\
\hline Madrid & 6.40 & 16 & 15 & 2.3 \\
\hline Galicia & 2.72 & 5 & 2 & 0.7 \\
\hline Andalousia & 8.30 & 11 & 3 & 0.4 \\
\hline Other $^{c}$ & 24.46 & 12 & 3 & 0.1 \\
\hline
\end{tabular}

aHHEV RNA detected from all cases, 50 HHEV3 strains identified, five strains could not be genotyped

${ }^{b}$ Restricted to the province of Leon from the region of Castile-Leon

${ }^{\mathrm{c}}$ Nine regions, cases found in Murcia, Valencia and Valladolid

Note: The four regions displaying the highest rates were clustered in the Northern third of the country. Rates were estimated from the total population of each region in 2010 but do not represent population-based data. 
study. ${ }^{18}$ However, differences in antibody prevalence have not yet been explored. Such regional variations could, if confirmed, help to identify the main ways for virus transmission, which remain largely speculative.

A study from Germany carefully investigated the risk factors of a significant number of patients with hepatitis $E .{ }^{13}$ Consumption of raw or undercooked beef and wild boar meat, pig offal, or pig internal organs other than liver were the only risk factor recorded in at least $20 \%$ of cases, and no factor was common to at least $50 \%$ of them. Consumption of raw or undercooked pork products was, however, almost as common among these patients as among the matched controls (78.6 vs. $66.4 \%$; OR=2.0). Therefore, the link between pork meat consumption and acquisition of hepatitis $E$ in Europe is not as clearly established by the epidemiological data as statements in the literature would suggest. There are, however, a few studies performed on pork derivatives that do favor this hypothesis. HHEV3 RNA has been amplified from pig liver, from sausage prepared with pig liver meat, and from sausage made of pig meat in Germany, France the United Kingdom, and Spain, ${ }^{54-58}$ and the presence of infectious virus in some of the PCR-positive products has been recently communicated. ${ }^{58}$

Sausage is a single English word used to describe a wide diversity of products that Europeans prepare in many different ways, displaying a wide range of specific names in other European languages. Since the way of preparation may influence the survival of the virus contaminating the pig meat, it remains to be identified what types of sausage are relevant for HHEV3 transmission and what are not. Consumption of air-dried pork "sausage" like chorizo is, for example, traditional in Spain and is consumed there more than any other European country. However, neither the frequency of hepatitis $E$ nor the prevalence of the infection seems significantly higher in Spain than in other countries of Europe, suggesting that chorizo is not a source of HHEV3 infections.

In regard to other means of transmission, water may be involved in the spreading of HHEV3 in Europe. The virus has been found in sewage or surface waters in Spain, Italy, and Slovenia, and these strains were genetically similar to those found in swine and humans in the region at the same time. 22,23,59 Contamination of water may lead to contamination of filtering shellfish, and HHEV3 RNA was found in mussels from different tidal locations of Scotland. ${ }^{60}$ On the west coast, up to $92 \%$ of the samples tested positive, and on the east coast, $55 \%$ of the samples tested positive. Phylogenetic analysis showed that most viral sequences clustered with HHEV3 isolates identified from humans and swine.

Transmission of HHEV3 to humans is likely, more or less, a frequent consequence of the complex ecological cycle of this promiscuous virus. Domestic and wild swine may be the main virus reservoirs and the source for contamination of surface water and sewage, which provides a vehicle to drive the infection to other wild and domestic species of mammals and to filtering mollusks. Humans can contract the virus at any of these levels, either directly from contaminated water or, more probable, through consumption of shellfish and domestic and wild species of meat. Finding common risk factors among a significant proportion of patients with hepatitis $E$ seems difficult when considerations are taken into account.

\section{Prevention of hepatitis E in Europe}

Public health actions for the prevention of hepatitis $E$ in Europe will require an extended knowledge about the sources of infection and the modes of transmission of HHEV3. It seems likely that such actions will mainly involve the field of alimentary safety, though specific proposals are at this time difficult to draw. Infections among transplant recipients and other immunocompromised patients will require specific preventative measures in the health care setting once the ways of transmission are identified. Recent reports suggest that European blood transfusion organizations should pay more attention to HHEV in the near future, as contaminated blood components and derivatives might be present in the blood supply.

Soon, immunization against HHEV by vaccination will provide a useful tool for the prevention of hepatitis $E^{61}$ Most efforts focus, however, on highly endemic regions where HHEV1 is prevalent, and trials have not been designed to explore the protection given to HHEV3. ${ }^{62,63}$ In addition, advanced investigations regarding the interaction of $\mathrm{HHEV}$ with the neutralizing antibody suggest there is some significant variability in the main epitopes among the genotypes and do not demonstrate conclusively that antibody against HHEV1 may protect efficiently against HHEV3. ${ }^{64}$ Vaccination could prevent the regular importation of the agent into Europe by protecting European travelers from acquiring HHEV1 abroad, but it is still uncertain if it could prevent autochthonous disease in the continent.

\section{Conclusions: what to do next?}

Recently, scientific research by groups from many European countries has multiplied our understanding in the continent of hepatitis E. The disease displays a unique dual character, including features of imported and autochthonous infections, involves the environmental characteristics of the waterborne and the zoonotic diseases, and sets at risk the alimentary safety. In addition, it may lead to serious health problems among patients with immune impairment because of organ transplant, cancer, or HIV infection. From its former consideration as a rare and mild imported disease, public health authorities now know that HHEV represents a local problem in Europe worthy of consideration. The WHO Regional Office for Europe and the ECDC should pay specific attention to hepatitis $E$ in the near future.

In my opinion, most of the research in the future on the continent should be both transnational and collaborative. In regard to diagnosis, accurate laboratory testing should be implemented for patients with acute viral hepatitis who test negative for other etiological agents or, even better, be included in routine screening strategies for the etiological diagnosis of the disease. In addition, standardization of laboratory testing through collaborative studies should be done to achieve consensus criteria for designing and evaluating prospective, population based studies about incidence and prevalence. Common protocols for the surveillance of infection among the immunocompromised should also be agreed upon. The organization of a European Network for Hepatitis E in connection with WHO and the ECDC, and with appropriate founding, would help to achieve these goals. The Iberian American Network for the Research of Hepatitis E, constituted in 2008 and accounting at present with participants from Argentina, Bolivia, Brazil, Cuba, Uruguay, Venezuela, and Spain, provides an example of how this kind of transnational collaboration can be very productive in the short term. ${ }^{7}$ 
Efforts in the clinical and public health fields should be accompanied by additional efforts regarding food and environment. Extended collaborative studies for detecting infectious HHEV 3 and 4 in different kinds of pork derivatives and in shellfish will be essential for evaluating the incidence of these viruses on food safety, which might account for most of the cases of hepatitis $E$ in Europe. Virus surveillance in wild fauna, surface water, and sewage would complement these activities. Since vaccination is an additional tool for prevention, either for the general population or for those segments at risk, studies dedicated to test the efficacy of the HHEV vaccines for protection against the HHEV3 infection should be done.

\section{Conflict of interest}

None

\section{Author contributions}

Conceiving and writing the manuscript (JME).

\section{References}

[1] Smith DB, Purdy MA, Simmonds P. Genetic variability and the classification of hepatitis E virus. J Virol 2013;87:4161-4169.

[2] Holla RP, Ahmad I, Ahmad Z, Jameel S. Molecular virology of hepatitis E virus. Sem Liver Dis 2013;33:3-14.

[3] Dalton HR, Stableforth W, Hazeldine S, Thurairajah P, Ramnarace R, Warshow $U$, et al. Autochthonous hepatitis $E$ in Southwest England: a comparison with hepatitis A. Eur J Clin Microbiol Infect Dis 2008;27:579585.

[4] Said B, Ijaz S, Kafatos G, Booth L, Thomas HL, Walsh A, et al. Hepatitis E outbreak on cruise ship. Emerg Infect Dis 2009;15:1738-1744.

[5] Kamar N, Rostaing L, Izopet J. Hepatitis E virus infection in immunossupressed patients: natural history and therapy. Sem Liver Dis 2013;33:6270.

[6] Drobeniuc J, Greene-Montfort T, Le N-T, Mixson-Hayden TR, Ganova-Raeva L, Dong C, Novak RT, et al. Laboratory-based surveillance for hepatitis E virus infection, United States, 2005-2012. Emerg Infect Dis 2013;19:218-222.

[7] Echevarría JM, González JE, Lewis-Ximénez LL, Lopes dos Santos DR, Munné MS, Pinto MA, et al. Hepatitis E virus infection in Latin America: a review. J Med Virol 2013;85:1037-1045.

[8] Echevarría JM. Light and darkness: prevalence of hepatitis E virus infection among the general population. Scientifica, in press.

[9] Kuniholm MH, Purcell RH, McQuillan GM, Engle RE, Wasley A, Nelson KE. Epidemiology of hepatitis $E$ virus in the United States: results from the Third National Health and Nutrition Examination Survey, 1988-1994. J Infect Dis 2009;200:48-56.

[10] Fogeda M, de Ory F, Avellón A, Echevarría JM. Differential diagnosis of hepatitis $E$ virus, cytomegalovirus and Epstein-Barr virus infection in patients with suspected hepatitis E. J Clin Virol 2009;45:259-261.

[11] Ijaz S, Arnold E, Banks M, Bendall RP, Cramp ME, Cunningham R, et al. Nontravel-associated hepatitis $\mathrm{E}$ in England and Wales: demographic, clinical, and molecular epidemiological characteristics. J Infect Dis 2005;192:11661172.

[12] Lewis HC, Boisson S, Ijaz S, Hewitt K, Ngui SL, Boxall E, et al. Hepatitis E in England and Wales. Emerg Infect Dis 2008;14:165-167.

[13] Wichmann O, Schimanski S, Koch J, Kohler M, Rothe C, Plentz A, et al. Phylogenetic and case-control study on hepatitis $E$ virus infection in Germany. J Infect Dis 2008;198:1732-1741.

[14] Romanò L, Paladini S, Tagliacarne C, Canuti M, Bianchi S, Zanetti AR. Hepatitis E in Italy: a long-term prospective study. J Hepatol 2011;54:3440.

[15] Candido A, Taffon S, Chionne P, Pisani G, Madonna E, Dettori S, et al. Diagnosis of HEV infection by serological and real-time PCR assays: a study on acute non-A-Chepatitis collected from 2004 to 2010 in Italy. BMC Res Notes 2012;5:297.

[16] Echevarría JM, Fogeda M, Avellón A. Diagnosis of acute hepatitis E by antibody and molecular testing: a studyon 277 suspected cases. J Clin Virol 2011;50:69-71.
[17] Mateos ML, Díez M, González-Galdameza A,Graus J, Moreno A, Pérez-Gracia MT. Acute, chronic and fulminant hepatitis $E$ : seven years of experience (2004-2011). Enferm Infecc Microbiol Clin 2013;31:595-598.

[18] Echevarría JM, Fogeda M, Avellón A. Update of cases of acute hepatitis E confirmed by the National Centre of Microbiology (Spain, 2004-2011). Enferm Infecc Microbiol Clin 2013;31:57-61.

[19] Kantala T, Maunula L, von Bonsdorff CH, Peltomaa J, Lappalainen M. Hepatitis $\mathrm{E}$ virus in patients with unexplained hepatitis in Finland. J ClinVirol 2009; 45: 109-113.

[20] Widén F, Sundqvist L, Matyi-Toth A, Metreveli G, Belák S, Hallgren G, et al. Molecular epidemiology of hepatitis $E$ virus in humans, pigs and wild boars in Sweden. Epidemiol Infect 2011;139:361-371.

[21] Pina S, Jofre J, Emerson SU, Purcell RH, Gironés R. Characterization of a strain of infectious hepatitis $\mathrm{E}$ virus isolated from sewage in an area where hepatitis $E$ is not endemic. Appl Environ Microbiol 1998;64:4485-4488.

[22] Clemente-Casares P, Rodríguez-Manzano J, Gironés R. Hepatitis E virus genotype 3 and sporadically also genotype 1 circulate in the population of Catalonia, Spain. J Water Health 2009;7:664-673.

[23] La Rosa G, Pourshaban M, Iaconelli M, Spuri V, Muscillo M. Molecular detection of hepatitis $\mathrm{E}$ virus in sewage samples. Appl Environ Microbio 2010;76:5870-5873.

[24] Díez-Valcarce M, Kokkinos P, Söderberg K, Bouwknegt M, Willems K, de Roda-Husman AM, et al. Occurrence of human enteric viruses in commercia mussels at retail level in three European countries. Food Environ Virol 2012; 4:73-80.

[25] De Silva AN, Muddu AK, Iredale JP, Sheron N, Khakoo SI, Pelosi E. Unexpectedly high incidence of indigenous acute hepatitis $E$ within South Hampshire: time for routine testing? J Med Virol 2008;80:283-288.

[26] Reuter G, Fodor D, Forgách P, KátaiA, Szucs G. Characterization and zoonotic potential of endemic hepatitis E virus (HEV) strains in humans and animals in Hungary. J ClinVirol 2009;44:277-281.

[27] Mansuy JM, Péron JM, Abravanel F, Poirson H, Dubois M, Miedouge M, et al. Hepatitis $E$ in the southwest of France in individuals who have never visited an endemic area. J Med Virol 2004;74:419-424.

[28] Herremans M, Bakker J, Duizer E, Vennema H, Koopmans MP. Use of serological assays for diagnosis of hepatitis $E$ virus genotype 1 and 3 infections in a setting of low endemicity. Clin Vaccine Immunol 2007;14: 562-568.

[29] Slot E, Hogema BM, Riezebos-Brilman A, Kok TM, Molier M, Zaaijer HL. Silent hepatitis E virus infection in Dutch blood donors, 2011 to 2012. Euro Surveill 2013;18:1-7.

[30] Juhl D, Baylis SA, Blümel J, Görg S, Hennig H. Seroprevalence and incidence of hepatitis $E$ virus infection in German blood donors. Transfusion, in press.

[31] Kamar N, Bendall RP, Péron JM, Cintas P, Prudhomme L, Mansuy JM, et al. Hepatitis E virus and neurologic disorders. Emerg Infect Dis 2011;17:173179.

[32] Despierres LA, KaphanE,Attarian S, Cohen-Bacrie S, Pelletier J, Pouget J, et al. Neurologic disorders and hepatitis E, France, 2010. Emerg Infect Dis 2011;17:1510-1512.

[33] Moal V, Legris T, Burtey S, Morange S, Purgus R, Dussol B, et al. Infection with hepatitis $\mathrm{E}$ virus in kidney transplant recipients in Southeastern France. J Med Virol 2013;85:462-471.

[34] Haagsma E, van den Berg AP, Porte RJ, Benne CA, Vennema H, Reimerink $\mathrm{JHJ}$, et al. Chronic hepatitis $\mathrm{E}$ virus infection in liver transplant recipients. Liver Transplant 2008;14:547-553.

[35] Pischke S, Stiefel P, Franz B, Bremer B, Suneetha PV, Heim A. Chronic hepatitis $E$ in heart transplant recipients. Am J Transplant 2012;12:31283133.

[36] Motte A, Roquelaure B, Galambrun C, Bernard F, Zandotti C, Colson P. Hepatitis $E$ in three immunocompromised children in southeastern France. J ClinVirol 2012;53:162-166.

[37] Kaba M, RichetH,Ravaux I, Moreau J, Poizot-Martin I, Motte A, et al. Hepatitis $E$ virus infection in patients infected with the human immunodeficiency virus. J Med Virol 2011;83:1704-1716.

[38] Neukam K, Barreiro P, Macías J, Avellón A, Cifuentes C, Martín-Carbonero L, et al. Chronic hepatitis $\mathrm{E}$ in HIV patients: rapid progression to cirrhosis and response to oral ribavirin. Clin Infect Dis 2013;57:465-468.

[39] Bouamra Y, Gérolami R, Arzouni JP, Grimaud JC, Lafforgue P, Nelli M, et al. Emergence of autochthonous infections with hepatitis $E$ virus of genotype 4 in Europe. Intervirology 2014;57:43-48.

[40] Garbuglia AR, Scognamiglio P, Petrosillo N, Mastroiaini CM, Sordillo P, Gentile D, et al. Hepatitis E virus genotype 4 outbreak, Italy, 2011. Emerg Infect Dis 2013;19:110-114

[41] Fogeda M, Avellón A, Cilla CG, Echevarría JM. Imported and autochthonous hepatitis E virus strains in Spain. J Med Virol 2009;81:1743-1749.

[42] Rossi-Tamisier M, Moal V, Gerolami R, Colson P. Discrepancy between antihepatitis $\mathrm{E}$ virus immunoglobulin $\mathrm{G}$ prevalence assessed by two assays in kidney and liver transplant recipients. J ClinVirol 2013;56:62-64. 
[43] Bernal W, Smith HM, Williams R. A community prevalence study on antibodies to hepatitis A and E in inner-city London. J Med Virol 1996;49: 230-234.

[44] Ijaz S, Vyse AJ, Morgan D, Pebody RG, Tedder RS, Brown D. Indigenous hepatitis $\mathrm{E}$ virus infection in England: more common than it seems. J Clin Virol 2009;44:272-276.

[45] Gessoni G, Manoni F. Hepatitis E virus infection in north-eastitaly: serological study in the open population and groups at risk. J Viral Hepat 1996;3:197202.

[46] Vulcano A, Angelucci M, Candelori E, Martini V, Patti AM, Mancini C, et al. HEV prevalence in the general population and among workers at zoonoticrisk in Latium Region. Ann Ig 2007;19:181-186.

[47] Rapicetta M, Kondili LA, Pretolani S, Stroffolini T, Chionne P, Villano U, et al. Seroprevalence and anti-HEV persistence in the general population of the Republic of San Marino. J Med Virol 1999;58:49-53.

[48] Buti M, Domínguez A, Plans P, Jardí R, Schaper M, Espuñes J, et al. Community-based seroepidemiological survey of hepatitis $E$ virus infection in Catalonia, Spain. ClinVaccine Immunol 2006;13:1328-1332.

[49] Buti M, Plans P, Domínguez A, Jardi R, Rodriguez Frias F, Esteban R, et al. Prevalence of hepatitis $E$ virus infection in children in the Northeast of Spain. Clin Vaccine Immunol 2008;15:732-734.

[50] Fogeda M, Avellón A, Echevarría JM. Prevalence of specific antibody to hepatitis $E$ virus in the general population of the Community of Madrid, Spain. J Med Virol 2012;84:71-74.

[51] Faber MS, Wenzel J], Jilg W, Thamm M, Höhle M, Stark K. Hepatitis E virus seroprevalence among adults, Germany. Emerg Infect Dis 2012;18:16541657.

[52] Verhoef F, Koopmans M, Duizer E, Bakker J, Reimerink J, van Pelt W. Seroprevalence of hepatitis $E$ antibodies and risk profile of HEV seropositivity in The Netherlands, 2006-2007. Epidemiol Infect 2012;140:1838-1847.

[53] Mansuy J-M, Bendall R, Legrand-Abravanel $F$, Sauné $K$, Miédouge $M$, Ellis $V$, et al. Hepatitis E virus antibodies in blood donors, France. Emerg Infect Dis $2011 ; 17: 2309-2312$
[54] Colson P, Borentain P, Queyriaux B, Kaba M, Moal V, Gallian P, et al. Pig liver sausage as a source of hepatitis $E$ virus transmission to humans. J Infect Dis 2010;202:825-834.

[55] Wenzel J], Preiß J, Schemmerer M, Huber B, Plentz A, Jilg W. Detection of hepatitis $E$ virus (HEV) from porcine livers in Southeastern Germany and high sequence homology to human HEV isolates. J Clin Virol 2011;52:50-54.

[56] Di Bartolo I, Díez-Valcarce M, Vasickova P, Kralik P, Hernández M, Angeloni G, et al. Hepatitis E virus in pork production chain in Czech Republic, Italy, and Spain, 2010. Emerg Infect Dis 2012;18:1282-1289.

[57] Berto A, Martelli F, Grierson S, Banks M. Hepatitis E virus in pork food chain, United Kingdom, 2009-2010. Emerg Infect Dis 2012;18:1358-1360.

[58] Berto A, Grierson S, Hakze-van der Honing R, Martelli F, Johne R, Reetz J, et al. Hepatitis E virus in pork liver sausage, France. Emerg Infect Dis 2013; 19:264-266.

[59] Steyer A, Naglič T, Močilnik T, Poljšak-Prijatelj M, Poljak M. Hepatitis E virus in domestic pigs and surface waters in Slovenia: prevalence and molecular characterization of a novel genotype 3 lineage. Infect Genet Evol 2011;11: 1732-1737.

[60] Crossan C, Baker PJ, Craft J, Takeuchi Y, Dalton HR, Scobie L. Hepatitis E virus genotype 3 in shellfish, United Kingdom. Emerg Infect Dis 2012;18: 2085-2087.

[61] Zhao Q, Zhang J, Wu T, Li SW, Ng MH, Xia NS, et al. Antigenic determinants of hepatitis $E$ virus and vaccine-induced immunogenicity and efficacy. J Gastroenterol 2013;48:159-168.

[62] Zhu FC, Zhang J, Zhang XF, Zhou C, Wang ZZ, Huang SJ, et al. Efficacy and safety of a recombinant hepatitis $E$ vaccine in healthy adults: a large-scale, randomised, double-blind placebo-controlled, phase 3 trial. Lancet 2010; 376:895-902.

[63] Zhang J, Zhang XF, Zhou C, Wang ZZ, Huang SJ, Yao X, et al. Protection against hepatitis $E$ virus infection by naturally acquired and vaccine-induced immunity. Clin Microbiol Infect 2013, in press.

[64] Tang X, Yang C, Gu Y, Song C, Zhang X, Wang Y, et al. Structural basis for the neutralization and genotype specificity of hepatitis E virus. Proc Natl Acad Sci U S A 2011;108:10266-10271 